Proceedings

\title{
Genetic Mutation and Variation in the GDF9 and BMPR1B Fecundity Genes of South African Indigenous Sheep Breeds ${ }^{\dagger}$
}

\author{
V. Booysen * and A.H. Molotsi
}

Citation: Booysen, V.; Molotsi, A.H.; Lastname, F. Genetic Mutation and Variation in the GDF9 and BMPR1B Fecundity Genes of South African Indigenous Sheep Breeds.

Proceedings 2021, 68, $\mathrm{x}$. https://doi.org/10.3390/xxxxx

Published: date

Publisher's Note: MDPI stays neutral with regard to jurisdictional claims in published maps and institutional affiliations.

Copyright: (c) 2021 by the authors. Submitted for possible open access publication under the terms and conditions of the Creative Commons Attribution (CC BY) license (http://creativecommons.org/licenses /by/4.0/).
Department of Animal Sciences, Stellenbosch University, Private Bag X1, Matieland,

Stellenbosch 7606, South Africa

* Correspondence: e-mail@e-mail.com

+ Presented at the 1st International Electronic Conference on Biological Diversity, Ecology and Evolution, 1531 March 2021; Available online: https://bdee2021.sciforum.net/.

\begin{abstract}
Genetic mutation occurs within genes and is responsible for the observed phenotypic variation between breeds within a species. It is known that indigenous sheep breeds are more robust and able to reproduce in adverse conditions in comparison to exotic sheep breeds. Therefore, the aim of this study was to determine whether there are any genetic mutations between indigenous breeds in known fecundity genes, growth differentiation factor 9 (GDF9) and bone morphogenetic protein receptor type 1B (BMPR1B/FecB), in four South African indigenous sheep breeds. A total of 52 blood samples were collected from four sheep breeds (Karakul = 8; Damara = 8; Zulu = 18; Pedi = 18). Unlabeled forward and reverse primers were used to amplify the GDF9 and BMPR1B genes. The PCR products were sequenced by a standard capillary sequencer. Sequencing results were analyzed using BioEdit, thereafter the detection of single nucleotide polymorphisms (SNPs), and phylogenetic analysis with the MEGA-X software. The results indicated that there are point mutations between sheep breeds in the GDF9 and BMPR1B gene compared to that of the Ovis aries complete coding sequence found in GenBank. Mutations of GDF9 gene (c.142C>T) and (c.151G>C) were detected in individuals of the Karakul, Damara, and Zulu sheep. The results also show that BMPR1B gene has mutation (c.80G>C) between individuals of the Zulu and Pedi sheep. Molecular phylogenetic analysis for both genes using the Neighbor-Joining method indicates relatedness between the Zulu and Pedi sheep. Damara breeds are more distantly related to Zulu and Pedi but show more relatedness with Karakul sheep. Polymorphism between and within the sheep breeds could be an indication of genetic variation that is potentially associated with higher prolificacy in indigenous sheep breeds.
\end{abstract}

Keywords: genetic variation; indigenous sheep; prolificacy; GDF9; BMPR1B

\section{Introduction}

Indigenous sheep are important genetic resources for subsistence and socio-economic livelihoods in developing countries (Hoffman, 2010) and provide a wide array of ecosystems goods and services facilitating many functions including food security, income source, savings, and transportation (Herrero, et al., 2013; Marshall, 2014; ILRI, 2019). The animals of smallholder farmers are kept under hot, humid, or dry areas where water and feed resources are scarce and disease incidence is high (Solkner, et al., 1998). These animals are not well characterised but have great potential to support the livelihoods of many rural societies due to high prevalence of animal genetic resources in the agro-ecosystem. Indigenous animals have great genetic diversity in productive and reproductive traits; however, smallholder farmers and pastoralists do not necessarily have the financial capacity and resources to capatilise on these traits.

Genetic variation with regards to reproduction efficiency in sheep has been documented extensively and the findings have been significant (Polley, et al., 2010). It has been 
reported that ovulation rate and litter size are important factors at improving reproductive capacity in sheep (Bradford, 1972). Studies have shown that ovulation rate and litter size can be regulated genetically by a set of genes known as fecundity (Fec) genes (Davis, et al., 1982). Three significant fecundity genes have been identified in sheep which includes the growth differentiation factor 9 (GDF9/FecG) on chromosome 5 (Hanrahan, et al., 2004), bone morphogenetic protein receptor type 1B (BMPR1B/FecB) on chromosome 6 and bone morphogenetic protein 15 (BMP15/FecX) on chromosome X (Hanrahan, et al., 2004; Galloway et al., 2000).

Fecundity genes have not been studied extensively in indigenous breeds in South Africa. Indigenous sheep are mostly kept by smallholder farmers and include Damara, Zulu, Pedi, Dorper and Namakwa Afrikaner (Molotsi, et al., 2017). The Damara sheep is a fat-tailed indigenous sheep breed that have the ability to lamb throughout the year and to thrive in arid and semidesert conditions in Southern Africa (Lerias, et al., 2016). The Karakul breed occur mostly in the Northern Cape province of the country, but some smallholder farmers in parts of the Western Cape province also keep Karakul sheep for subsistence. Zulu sheep is one of the Nguni-type sheep breed and are mainly kept by smallholder farmers in the Kwazulu-Natal province. Zulu sheep are adapted to the high rainfall and humid climate in the east-coast region (Kunene \& Fossey, 2006). It has been reported that the Zulu sheep breed has a broad ancestral gene pool which may contain genes necessary for future generations. The Pedi sheep is also a Nguni-type sheep and kept primarily by smallholder farmers in the Limpopo province. The Pedi sheep is regarded as an early maturing breed with high reproductive rates (Louw, 2015).

Indigenous sheep breeds are known to have high genetic diversity that enables them to thrive under adverse environmental conditions. Characterisation of fecundity genes in indigenous sheep holds potential to enhance genetic improvement strategies and breeding programs. The aim this study was therefore to determine the presence of genetic mutations between indigenous breeds in the GDF9 and BMPR1B fecundity genes in four South African indigenous sheep breeds.

\section{Materials and methods}

\subsection{Animals and Sampling}

Ethical approval for blood sample acquisition was granted by the Research Ethics Committee (Animal Care and Use) at Stellenbosch University. This study was conducted on indigenous sheep breeds from smallholder farmers in the Western Cape, Northern Cape, and Kwazulu-Natal provinces in South Africa. A total of 52 blood samples were collected from 4 breeds $($ Karakul $=8 ;$ Damara $=8 ; \mathrm{Zulu}=18 ;$ Pedi $=18)$. Venous blood was collected from the jugular vein of each animal and placed in a $0.5 \mathrm{~mL} 2.7 \%$ EDTA (ethylene diamine tetra acetate) vacutainer tube and stored on ice, thereafter, transferred to the molecular laboratory freezer under $-4^{\circ} \mathrm{C}$.

\subsection{DNA Isolation}

Ovine genomic DNA was extracted from the blood samples using the sbeadex ${ }^{\mathrm{TM}}$ livestock kit. DNA quantification was measured using the Nanodrop ${ }^{\mathrm{TM}}$ Spectrophotometer. Electrophoretic separation of each DNA sample was undertaken on a $2 \%$ agarose gel in 10x TBE buffer to investigate the DNA quality.

\subsection{Primers}

The GDF9 and BMPR1B genes were amplified by using a set of unlabeled forward and reverse primers. Primers were obtained from literature based on the sequences described by (Davis, et al., 2002): GDF9 forward (5'GAAGACTGGTATGGGGAAATG3') and reverse (5'CCAATCTGCTCCTACACACCT3'); BMPR1B forward (5'CCAGAGGACAATAGC AAAGCAAA3') and reverse (5'CAAGATGTTTTCATGCCTCATCAAGGT3') Table 1. 
Table 1. Primers (forward and reverse) with properties used for amplification of GDF9 and BMPR1B genes.

\begin{tabular}{ccccc}
\hline Gene & Primer sequence $\left(\mathbf{5}^{\prime} \mathbf{- 3}^{\prime}\right)$ & Mol Weight & Tm $\left({ }^{\circ} \mathbf{C}\right)$ & GC Content $(\mathbf{\%})$ \\
\hline GDF9 & (F) GAAGACTGGTATGGGGAAATG & 6599.3 & 53.0 & 47.6 \\
& (R) CCAATCTGCTCCTACACACCT & 6246.1 & 56.6 & 52.4 \\
BMPR1B & (F) CCAGAGGACAATAGCAAAGCAAA & 7092.7 & 55.7 & 43.5 \\
& (R) CAAGATGTTTTCATGCCTCATCAAGGT & 9430 & 61.3 & 45.2 \\
\hline
\end{tabular}

(F) indicates forward primer and (R) reverse primer; PCR and electrophoretic separation.

A gene specific PCR (Polymerase Chain Reaction) was carried out on the MiniAmp ${ }^{\mathrm{TM}}$ Thermo Cycler. PCR of GDF9 and BMPR1B genes was conducted by mixing $25 \mu \mathrm{L}$ Thermo Scientific Master Mix, $2 \mu \mathrm{L}$ DNA template, $3 \mu \mathrm{L}$ forward primer, $3 \mu \mathrm{L}$ reverse primer and $17 \mu \mathrm{L}$ nuclease free water, producing total of $50 \mu \mathrm{L}$ PCR reaction volume. The amplification process constituted 35 cycles at $95^{\circ} \mathrm{C}$ for $5 \mathrm{~min}$, followed by $95^{\circ} \mathrm{C}$ for $30 \mathrm{~s}$ (denaturation), $60{ }^{\circ} \mathrm{C}$ for 90 (annealing), $72{ }^{\circ} \mathrm{C}$ for $30 \mathrm{~s}$ (extension), and final extension at $72{ }^{\circ} \mathrm{C}$ for $10 \mathrm{~min}$. The separation of PCR product was done on a $1.2 \%$ agarose gel electrophoresis unit in 10x TBE buffer and visualized with Conda Safe nucleic acid staining solution.

\subsection{Bioinformatic Analysis}

DNA sequencing results were analyzed with the BioEdit program, followed by detection of single nucleotide polymorphisms (SNPs), and phylogenetic analysis with the MEGA-X software. The identification of point mutations in the GDF9 and the BMPR1B genes was carried out by aligning the sequence data and comparing it to the complete coding sequence of Ovis aries. Individuals that did not show nucleotide difference compared to Ovis aries were excluded from the from Figures 1 and 2. Sites with ambiguous data and gaps were excluded from the alignment. The molecular phylogenetic analysis was done using the Neighbor-Joining method.

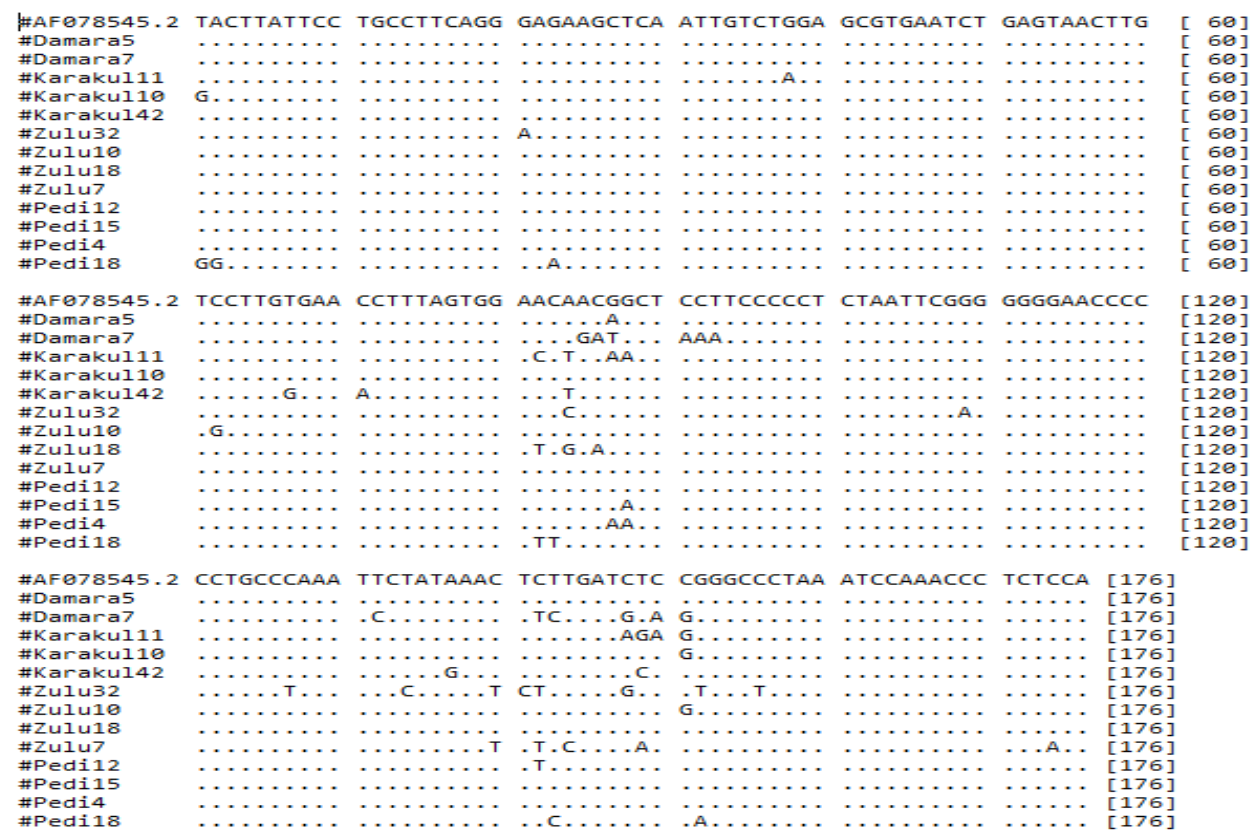

Figure 1. Multiple sequence alignment of nucleotide sequence of GDF9 gene of indigenous sheep under study with that of Ovis aries complete coding sequence (AF078545.2). Sites with ambiguous data and gaps was excluded from the alignment. The '.' Illustrates the nucleotides that match the consensus sequence. 


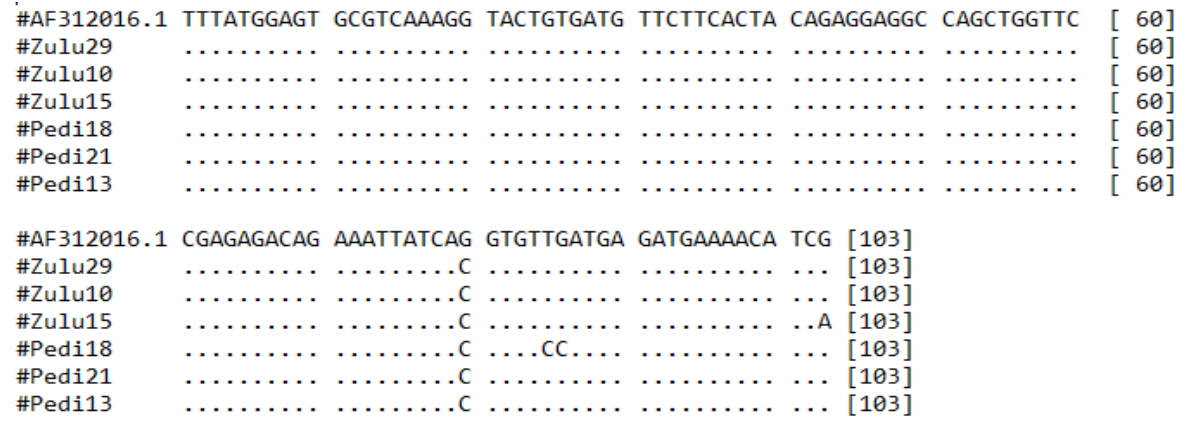

Figure 2. Multiple sequence alignment of nucleotide sequence of BMPR1B gene of indigenous sheep under study with that of Ovis aries complete coding sequence (AF312016.1). Sites with ambiguous data and gaps was excluded from the alignment. The '.' Illustrates the nucleotides that match the consensus sequence.

\section{Results and Discussion}

Genetic variation in the GDF9 gene was present in individuals from all four sheep breeds under study Figure 1. Thirteen individuals in total had point mutations at various sites. There is a lot of genetic variation in the GDF9 gene between sheep breeds compared to the consensus sequence Ovis aries. Some significant point mutations in the Karakul, Damara and Zulu sheep breeds were (c.142>T) and (c.151G>C). The results also show genetic variation in the FecB gene with mutation $(\mathrm{c} .80 \mathrm{G}>\mathrm{C}$ ) between individuals of Zulu and Pedi sheep Figure 2. Three Pedi sheep and Zulu sheep respectively had a significant point mutation compared to the consensus sequence However, there is not so much genetic variation between the Pedi and Zulu sheep compared to the consensus sequence, Ovis aries.

The GDF9 and BMPR1B genes have been studied quite extensively and reported to be closely linked to prolificacy in sheep (Polley, et al., 2010; Souza, et al., 2001). Fabre et al., (2006) suggest that ovulation rate and the consequent litter size in sheep increase with increasing mutations in the BMPR1B gene (Fabre, et al., 2006). The FecB mutation of the BMPR1B gene has been reported in some of the world's most prolific sheep breeds such as the Indian Garole (Fabre, et al., 2006), Australian Booroola Merino (Souza, et al., 2001) and the small-tailed Han Hu Sheep (Davis, et al., 2002).

The sequence information of the GDF9 and BMPR1B genes of the sheep breeds was compared with the published complete coding sequences of Ovis aries, AF078545.2 and AF312016.1 respectively Figure 4. Phylogenetic analysis on the basis of nucleotide sequences for the GDF and BMPR1B gene revealed relatedness between the Zulu and Pedi sheep. Damara breeds were distantly related to Zulu and Pedi but showed more relatedness to Karakul sheep.
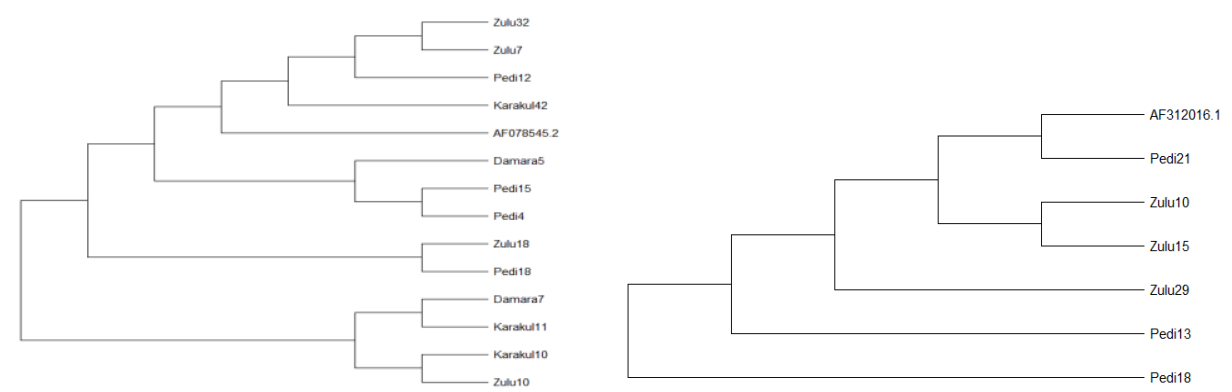

Figure 4. Molecular phylogenetic analysis on the basis of nucleotide sequences of the fecundity genes under study with that of the Ovis aries complete coding sequence with accession numbers AF078545.2 (GDF9) and AF312016.1 (BMPR1B). 


\section{Conclusions}

The four sheep breeds under study (Damara, Karakul, Zulu, Pedi) have been found to have the GDF9 gene and the Zulu and Pedi sheep the BMPR1B Booroola gene. The presence of these genetic markers could point to high reproductive capacity in terms of ovulation rate and the subsequent litter size. This is an indication that these sheep are most likely prolific sheep breeds. The findings of this study suggest that genetic variation in the GDF9 and BMPR1B fecundity genes is important to reproductive capacity in indigenous sheep breeds given their hot and arid production environments. This study is limited, therefore more extensive research is mandatory with increased sample sizes, incorporation of lambing records and more rigorous genetic analysis.

\section{Author Contributions:}

Funding:

\section{Institutional Review Board Statement:}

Informed Consent Statement:

Data Availability Statement:

Conflicts of Interest: The authors declare no conflict of interest.

\section{References}

1. Bradford, G.E. Genetic control of litter size in sheep. J. Reprod. Fertil 1972, 15, 23-41.

2. Davis, G.H.; Galloway, S.M.; Ross, I.K.; Gregan, S.M.; Ward, J.; Nimbkar, B.V.; Ghalsasi, P.M.; Nimbkar, C.; Gray, G.D.; Inounu, I.; et al. DNA tests in prolific sheep from eight countries provide new evidence on the origin of the Booroola (FecB) mutation. Biolol. Reprod. 2002, 66, 1869-1874.

3. Davis, G.H.; Montgomery, G.W.; Allison, A.J.; Kelly, R.W.; Bray, A.R. Segregation of major gene influencing fecundity in progeny of Booroola sheep. N. Z. J. Agric. Res. 1982, 25, 525-529.

4. Fabre, S.; Pierre, A.; Mulsant, P.; Bodin, L.; Di Pasquale, E.; Persani, L.; Monget, P.; Monniaux, D. Regulatiate of ovulation rate in mammals: Contribution of sheep genetic models. Reprod. Biol. Endocrinol. 2006, 4, 20.

5. Galloway, S.M.; McNatty, K.P.; Cambridge, L.M.; Laitinen, M.P.; Juengel, J.L.; Jokiranta, T.S.; McLaren, R.J.; Luiro, K.; Dodds, K.G.; Montgomery, G.W.; et al. Mutations in an oocyte-derived growth factor gene (BMP15) cause increased ovulation rate and infertility in a dosage-sensitive manner. Nat. Genet. 2000, 25, 279-283.

6. Hanrahan, J.P.; Gregan, S.M.; Mulsant, P.; Mullen, M.; Davis, G.H.; Powell, R.; Galloway, S.M. Mutations in the genes for oocytederived growth factors GDF9 and BMP15 are associated with both increases ovulation rate and sterility in Cambridge and Belclare sheep (Ovis aries). Biol. Reprod. 2004, 70, 900-909.

7. Herrero, M.; et al. The roles of livestock in developong countries: The good, the bad and the knowledge gaps. Animal 2013, 7, $3-18$.

8. Hoffman, I. Climate and characterization, breeding and conservation of animal genetic resources. Anim. Genet. 2010, 41, 32-46.

9. ILRI. Options for the Livestock Sector in Developomg and Emerging Economies to 2030 and Beyond; Gene, Meat: The Future Series; 2019.

10. Kunene, N.W.; Fossey, A. A survey on the livestock production in some tradition areas at Northern KwaZulu-Natal in South Africa. Lives. Res. Rural. Dev. 2006, 18, 30-33.

11. Lérias, J.R.; Kilminster, T.; Scanlon, T.; Milton, J.; Oldham, C.; Greeff, J.C.; Martins, L.L.; Mourato, M.P.; Almeida, A.M. The fattail of Damara sheep: An assessment of mineral content as influenced by weight loss. Anim. Prod. Sci. 2016, 56, 1492-1495.

12. Louw, M. Indigenous Sheep Breeds in South Africa; Online: 2015. Available online: http://www.southafrica.co.za/indigenous sheep breeds in south africa (accessed on 28 February 2021).

13. Molotsi, A.; Dube, B.; Oosting, S.; Marandure, T.; Mapiye, C.; Cloete, S.; Dzama, K. Genetic traits of relevance to sustainability of smallholder sheep farming systems in South Africa. Sustainability (Switz.) 2017, 9, 1225, doi:10.3390/su9081225.

14. Polley, S.; De, S.; Brahma, B.; Mukherjee, A.; Vinesh, P.V.; Batabyal, S.; Arora, J.S.; Pan, S.; Samanta, A.K.; Datta, T.K.; Goswami, S.L. Polymorphism of BMPR1B, BMP15 and GDF9 fecundity genes in prolific Garole sheep. Trop. Anim. Health Prod. 2010, 42, 985-993, doi:10.1007/s11250-009-9518-1.

15. Solkner, J.; Nakimbugwe, H.; Valle Zárate, A. Analysis of the determinants for success and failure of village breeding programmes. In Proceedings of the 6th Wold Congress on Genetics Applied to Livestock, Armidale, Australia, 11-16 January 1998; Volume 25, pp. 273-280.

16. Souza, C.J.H.; MacDougall, C.; Campbell, B.K.; McNeilly, A.S.; Baird, D.T. The Booroola (FecB) phenotype is associated with a mutation in the bone morphogenetic receptor 1 B (BMPR1B) gene. J. Endocrinol. 2001, 169, R1. 